\title{
Development of Robust Heterogeneous Chiral Rhodium Catalysts Utilizing Acid-base and Electrostatic Interactions for Efficient Continuous-Flow Asymmetric Hydrogenations
}

\author{
Yuki Saito and Shū Kobayashi
}

shu_kobayahsi@chem.s.u-tokyo.ac.jp

Department of Chemistry, School of Science, The University of Tokyo, 7-3-1, Hongo, Bunkyo-ku, Tokyo, 113-0033, JAPAN

\section{Supporting Information}

Contents

1. General

2. A general procedure of preparation of Rh-QuinoxP*/STA/KIT-6-NH2

3. A general procedure of evaluation of Rh loading

4. Characterization of Rh-QuinoxP*/STA/KIT-6

5. A general procedure of the continuous-flow hydrogenation of enamide

6. A general procedure of substrate scope in the continuous-flow hydrogenation of enamides

7. Optimization and a general procedure for o-substituted enamides

8. Optimization and a procedure for 2-Naph substituted enamides

9. Comparison with batch and flow system

10. Product data

11. NMR and HPLC data

12. References 


\section{General}

- JEOL JNM-ECA 500 or ECX 600 spectrometers were used for NMR measurement. Tetramethyl silane was used as an internal standard for ${ }^{1} \mathrm{H}-\mathrm{NMR}(\delta=0 \mathrm{ppm})$, and deuterated chloroform was used for ${ }^{13} \mathrm{C}-\mathrm{NMR}(\delta=77.36 \mathrm{ppm})$. Structures of known compounds were confirmed by comparing with data shown in literature.

- JEOL ECZ 600 was used for solid NMR measurement. CP-MAS method was used for ${ }^{13} \mathrm{C}$, ${ }^{29} \mathrm{Si}$, and ${ }^{31} \mathrm{P}$ NMR measurements.

- Nitrogen absorption/desorption isotherm was recorded on a BELSORP-mini Microtrac Bell.

- ICP-AES analysis was performed on Shimadzu ICPS-7510 equipment.

- HPLC analysis was performed on Shimadzu LC-20AB, SPD-M20A, and DGU-20A3 with chiral columns from DAICEL corporation.

- Centrifugation was carried out using Kokusan H-36 $\alpha$.

- Preparative thin-layer chromatography was carried out using Wakogel B-5F.

- Solvents were purchased in anhydrous grade from Wako Pure Chemical Company. All solvents were degassed by Freeze-Pump-Thaw cycle just before use.

- $\left[\mathrm{Rh}(\mathrm{nbd})_{2}\right] \mathrm{BF}_{4}$ were purchased from Strem Chemical Inc..

- mesoporous silica (KIT-6 and SBA-15) was prepared by following reported methods ${ }^{1}$ and characterized by $\mathrm{N} 2$ ads./des. isotherm.

- CARiACT-Q10 was purchased from Fuji Silysia Chemical Ltd..

- Aluminum oxide (90, active basic) was purchased from Sigma-Aldrich Co. LLC..

- Amino propyl triethoxysilane was purchased from Tokyo Chemical Industry Co., Ltd..

- QuinoxP* was prepared by following reported methods. ${ }^{2}$

- BenzP* was purchased from Nippon Chemical Industrial Co., Ltd..

- Other chiral ligands were prepared by following reported methods. ${ }^{3,4}$

- Enamides 2 and dehydroamino acids 4 were prepared from commercially available starting materials by following reported methods. ${ }^{5-8}$

- Racemic samples for products were prepared by following reported methods. ${ }^{9,10}$

- All commercially-available reagents, unless otherwise stated, were used without further purification.

- All reactions, unless otherwise stated, were carried out under argon atmosphere. 
2. A general procedure of preparation of Rh-QuinoxP*/STA/KIT-6- $\mathrm{NH}_{2}$

(a) Surface amine functionalization

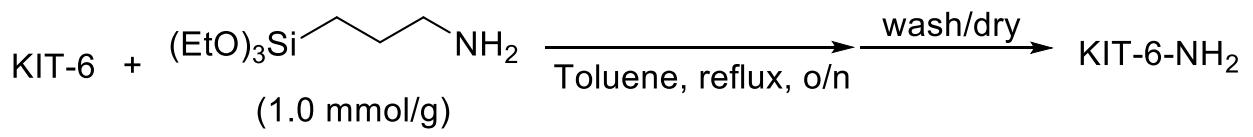

(b) Salt formation with silicotungstic acid(STA)

STA

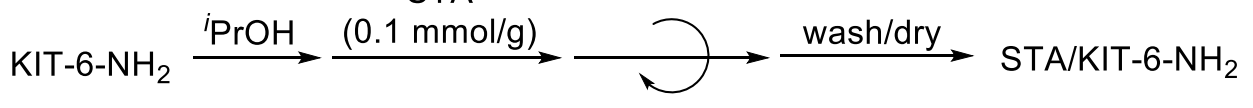

$\mathrm{rt}, \mathrm{o} / \mathrm{n}$

(c) Immobilization of chiral Rh complex

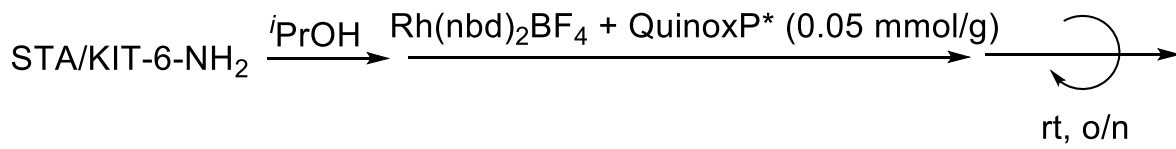

centrifuge

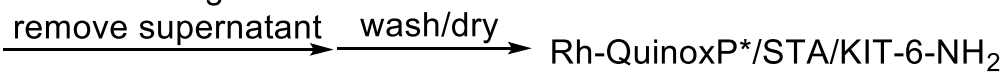

2.(a) A general procedure for the functionalization of KIT-6

KIT- 6 was prepared by following reported method with variety of aging temperature. Material with $100{ }^{\circ} \mathrm{C}$ aging temperature is referred as KIT-6, while the one with $80{ }^{\circ} \mathrm{C}$ aging temperature is referred as KIT- $6-\mathrm{L}$, and the one with $120^{\circ} \mathrm{C}$ aging temperature is referred as KIT-6-H. The preparation was quite reproducible and the yields of several preparations were 94-98\%.

To a $100 \mathrm{~mL}$ round bottom flask equipped with magnetic stirring bar and reflux condenser was added KIT-6 (2.0 g). KIT- 6 was dried under vacuo at $100{ }^{\circ} \mathrm{C}$ for $1 \mathrm{~h}$. After cooling to room temperature, Ar balloon was equipped. Toluene $(50 \mathrm{~mL})$ was added to the flask followed by the addition of amino propyl triethoxysilane $(442.7 \mathrm{mg}, 2.0 \mathrm{mmol})$. The mixture was reflux for $15 \mathrm{~h}$. After cooling to room temperature, The solid was collected by filtration, and washed with Toluene $(20 \mathrm{~mL} * 3)$ and THF $\left(20 \mathrm{~mL}^{*} 2\right)$. Finally, the solid was dried under vacuo at room temperature for $3 \mathrm{~h}$ to get $\mathrm{KIT}-6-\mathrm{NH}_{2}$ as a white solid $(2.41 \mathrm{~g})$.

2.(b) A general procedure for the salt formation with STA

To a $100 \mathrm{~mL}$ round bottom flask equipped with magnetic stirring bar was added KIT- $6-\mathrm{NH}_{2}$ $(2.0 \mathrm{~g}) .{ }^{i} \mathrm{PrOH}(30 \mathrm{~mL})$ was added to the flask followed by the addition of the solution of STA (661 mg, $0.2 \mathrm{mmol})$ in ${ }^{i} \mathrm{PrOH}(20 \mathrm{~mL})$. The mixture was stirred for $15 \mathrm{~h}$ at room temperature. The solid was collected by filtration, and washed with ${ }^{i} \mathrm{PrOH}\left(20 \mathrm{~mL}{ }^{*} 3\right)$ and THF $\left(20 \mathrm{~mL}^{*} 2\right)$. 
Finally, the solid was dried under vacuo at room temperature for $3 \mathrm{~h}$ to get STA/KIT-6- $\mathrm{NH}_{2}$ as a white solid $(2.60 \mathrm{~g})$.

2.(c) A general procedure for the immobilization of Rh complex

To an oven dried test tube equipped with magnetic stirring bar was added STA/KIT- $6-\mathrm{NH}_{2}$ $(100 \mathrm{mg})$. The solid was dried under vacuo at room temperature for $1 \mathrm{~h}$. Meanwhile, to an another oven died test tube was added $\mathrm{Rh}(\mathrm{nbd})_{2} \mathrm{BF}_{4}(1.9 \mathrm{mg}, 0.005 \mathrm{mmol})$ and QuinoxP* $(1.8 \mathrm{mmol}, 0.0055 \mathrm{mmol})$. iPrOH $(1 \mathrm{~mL})$ was added to the flask, and the solution was stirred at room temperature for $1 \mathrm{~h}$ to give orange solution of Rh-QuinoxP* complex. ${ }^{i} \mathrm{PrOH}(1 \mathrm{~mL})$ was added to the flask with support material, and the solution of Rh complex via cannula. The mixture was stirred for $3 \mathrm{~h}$ at room temperature. The flask was centrifuged at 3,000 rpm for $15 \mathrm{~min}$. After completion of centrifugation, the supernatant was removed by cannula. To the flask ${ }^{\mathrm{P} O \mathrm{OH}}(2 \mathrm{~mL})$ was added and stirred for $10 \mathrm{~min}$ at room temperature. This washing process was repeated for 5 times, and after removal of supernatant, the solid was dried under vacuo at room temperature for $3 \mathrm{~h}$. The Rh-QuinoxP*/STA/KIT-6-NH $\mathrm{N}_{2}$ was obtained as orange solid (101 mg).

3. A general procedure for the Rh loading evaluation.

- KIT-6 was used as prepared and dried under vacuo at room temperature for $1 \mathrm{~h}$ before use.

- KIT-6/ $\mathrm{NH}_{2}$ was used as prepared by following procedure 2.(a).

- STA/KIT-6 was used as prepared by following procedure 2.(b) without surface amine functionalization.

Immobilization of $\mathrm{Rh}$ complex to each support was performed by following the procedure of 2(c). Obtained solid $(10 \mathrm{mg})$ was decomposed by the treatment of $\mathrm{HF}$ aq. at room temperature to get clear solution. The solution was diluted with $\mathrm{H}_{2} \mathrm{O}$ up to $25 \mathrm{~mL}$, and the solution was analyzed by ICP-AES to determine the actual loading concentration of Rh. The efficiency was calculated by the following equation.

Efficiency $(\%)=($ actual loading $(\mathrm{mmol} / \mathrm{g})) /($ target loading $(\mathrm{mmol} / \mathrm{g})) * 100$

Table S1. Support Effect on Immobilization

\begin{tabular}{|c|c|c|c|}
\hline Entry & Support & ${\text { Loading }(\mathrm{mmol} / \mathrm{g})^{\mathrm{a}}}$ & ${\text { Efficiency }(\%)^{\mathrm{b}}}^{\mathrm{a}}$ \\
\hline 1 & STA/KIT-6-NH & & $>99$ \\
\hline 2 & KIT-6 & $<10^{-4}$ & $<1$ \\
\hline 3 & KIT-6-NH $_{2}$ & $<10^{-4}$ & $<1$ \\
\hline
\end{tabular}




\begin{tabular}{|l|l|l|c|}
\hline 4 & STA/KIT-6 & 0.0045 & 8 \\
\hline
\end{tabular}

The loading concentration of the Rh was determined to be $0.0495 \mathrm{mmol} / \mathrm{g}$ by ICP analysis, and the target loading was $0.05 \mathrm{mmol} / \mathrm{g}$. This means $>99 \%$ of the $\mathrm{Rh}$ complex was immobilized on the support, which suggests strong interaction with the support material (Table 1, entry 1). No immobilization was observed in the absence of STA, indicating the importance of electrostatic interactions between the Rh center and STA (Table 1, entries 2 and 3). Similarly, in the absence of amine functionality on the surface of KIT-6, almost no Rh was observed (Table 1, entry 4). These control experiments indicate the importance of both acid-base interaction and electrostatic interaction.

\section{Characterization of Rh-QuinoxP*/STA/KIT-6-NH}

To assess whether the surface functionalization was taking place inside the mesopores, $\mathrm{N}_{2}$ adsorption/desorption isotherms were measured for each step (Figure S1(a)). All the materials showed type IV hysteresis in the ads./des. isotherm, indicating that the mesoporous structure was maintained during each step. Furthermore, when the internal surface area and outer surface area were calculated (Figure S1(b)), a significant decrease of the internal surface area was observed during functionalization, while the outer surface area remained almost unchanged. These results strongly suggest that each functionalization occurred inside the mesopores. More detailed characterization was obtained based on analysis by solid-state NMR spectroscopy (Figure S4), scanning transmission electron microscopy (STEM) (Figure S2) and energy dispersive X-ray spectroscopy (EDS) (Figure S3). Solid-state ${ }^{13} \mathrm{C}$ and ${ }^{29} \mathrm{Si}$ NMR analysis indicated that two or three OMe groups on silane coupling reagents were replaced with $\mathrm{Si}-\mathrm{OH}$ on the $\mathrm{SiO}_{2}$ surface, and ${ }^{31} \mathrm{P}$ NMR analysis indicated the existence of a cationic Rh-ligand complex and the absence of a free ligand. STEM analysis confirmed the mesoporous structure of the support and no aggregation of Rh species was observed by EDS mapping. All the characterization data were consistent with our target structure in which chiral cationic Rh complexes were immobilized inside mesopores by ionic interactions with STA.

(a) 


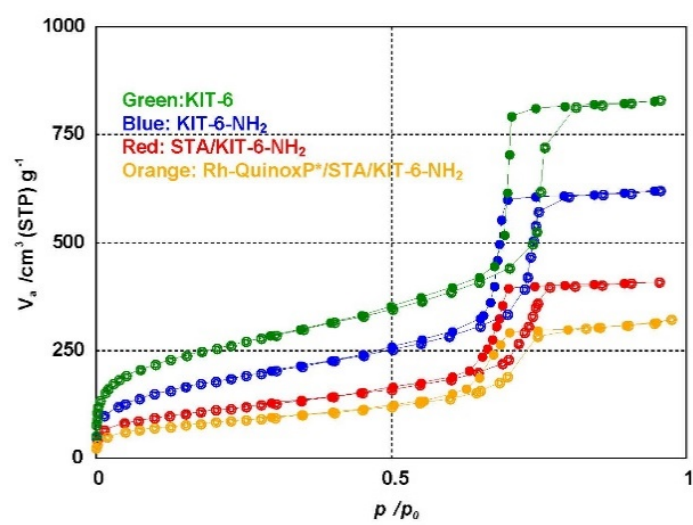

(b)

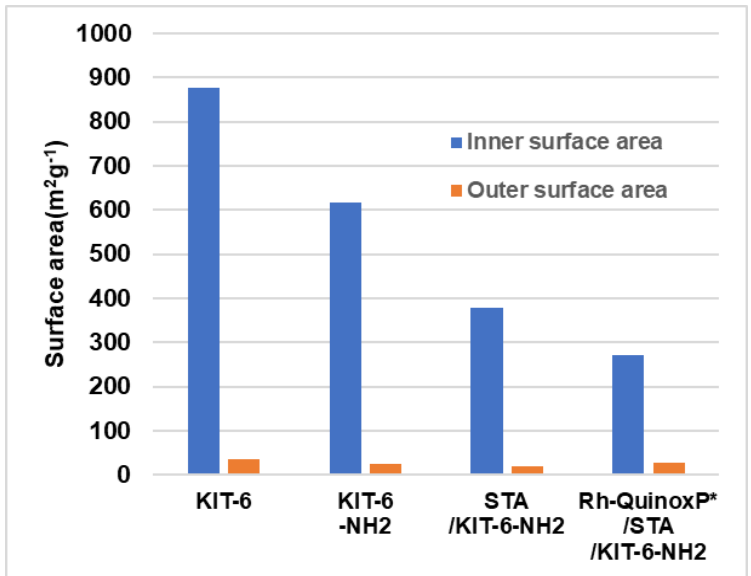

Figure S1. (a) $\mathrm{N}_{2}$ ads./des. isotherm (b) Comparison of surface area.

Table S2. Comparison of Inner Surface Area and Outer Surface Area

\begin{tabular}{|c|c|c|c|}
\hline Material & $\begin{array}{c}\text { Inner surface area }{ }^{\mathrm{a}} \\
\left(\mathrm{m}^{2} \mathrm{~g}^{-1}\right)\end{array}$ & $\begin{array}{c}\text { Outer surface area } \\
\left(\mathrm{m}^{2} \mathrm{~g}^{-1}\right)\end{array}$ & $\begin{array}{c}\text { Pore volume } \\
{ }^{\mathrm{c}}\left(\mathrm{cm}^{3} \mathrm{~g}^{-}\right.\end{array}$ \\
\hline KIT-6 & 877.52 & 35.819 & 1.2823 \\
\hline KIT-6-NH 2 & 617.55 & 24.017 & 0.9592 \\
\hline STA/KIT-6-NH2 & 379.31 & 20.892 & 0.6323 \\
\hline $\begin{array}{c}\text { Rh- } \\
\text { QuinoxP*/STA/KIT-6- } \\
\text { NH2 }\end{array}$ & 271.32 & 27.40 & 0.4980 \\
\hline
\end{tabular}

${ }^{a}$ Calculated by t-plot analysis, ${ }^{\mathrm{b}}$ Total surface area was calculated by BET method. Outer surface area was calculated by difference from total surface area and inner surface area. ${ }^{c}$ calculated by BET method. 

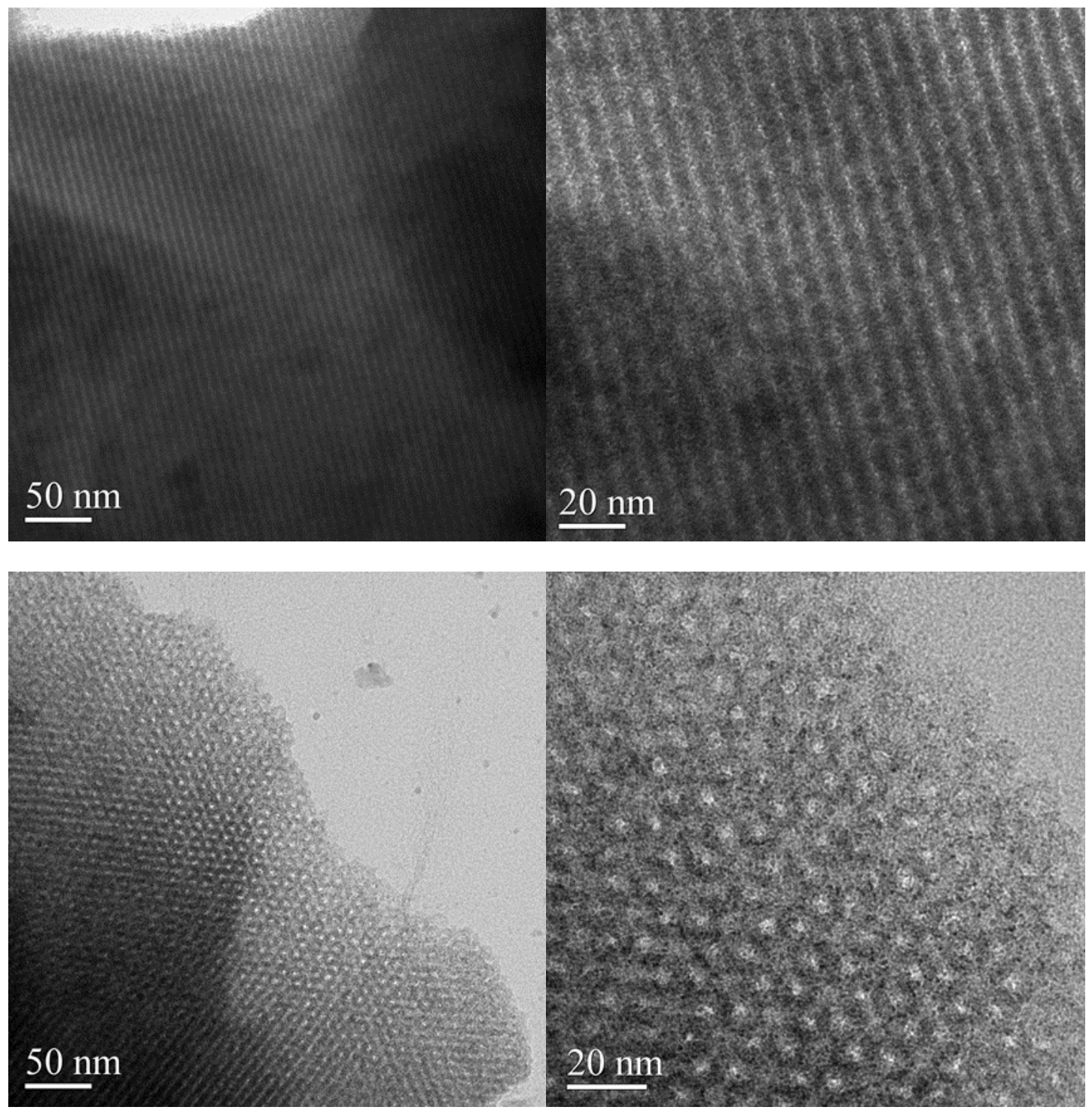

Figure S2. STEM Images of Rh-QuinoxP*/STA/KIT-6-NH $\mathrm{N}_{2}$ 

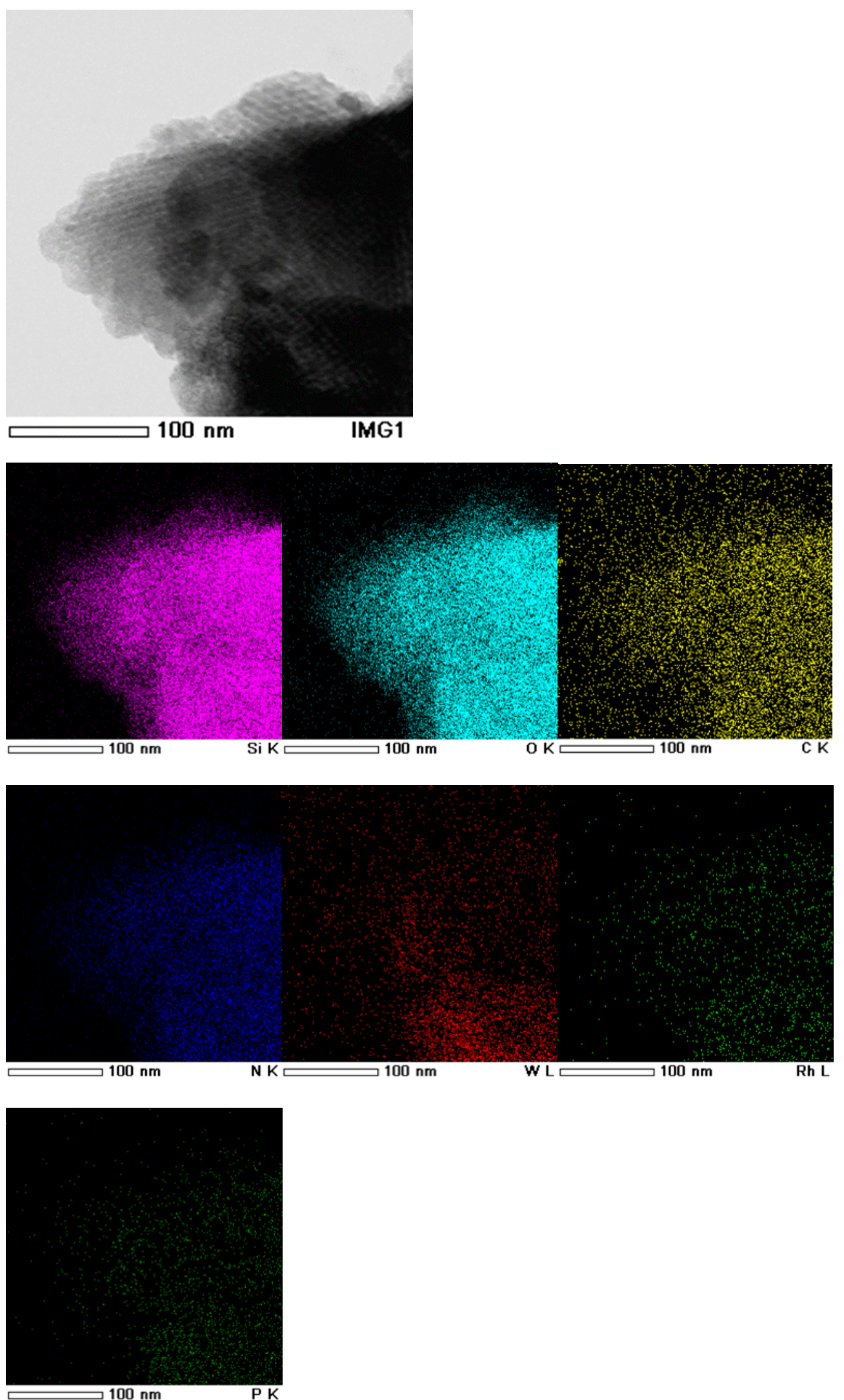

Figure S3. EDS mapping of Rh-QUinoxP*/STA/KIT-6-NH2 

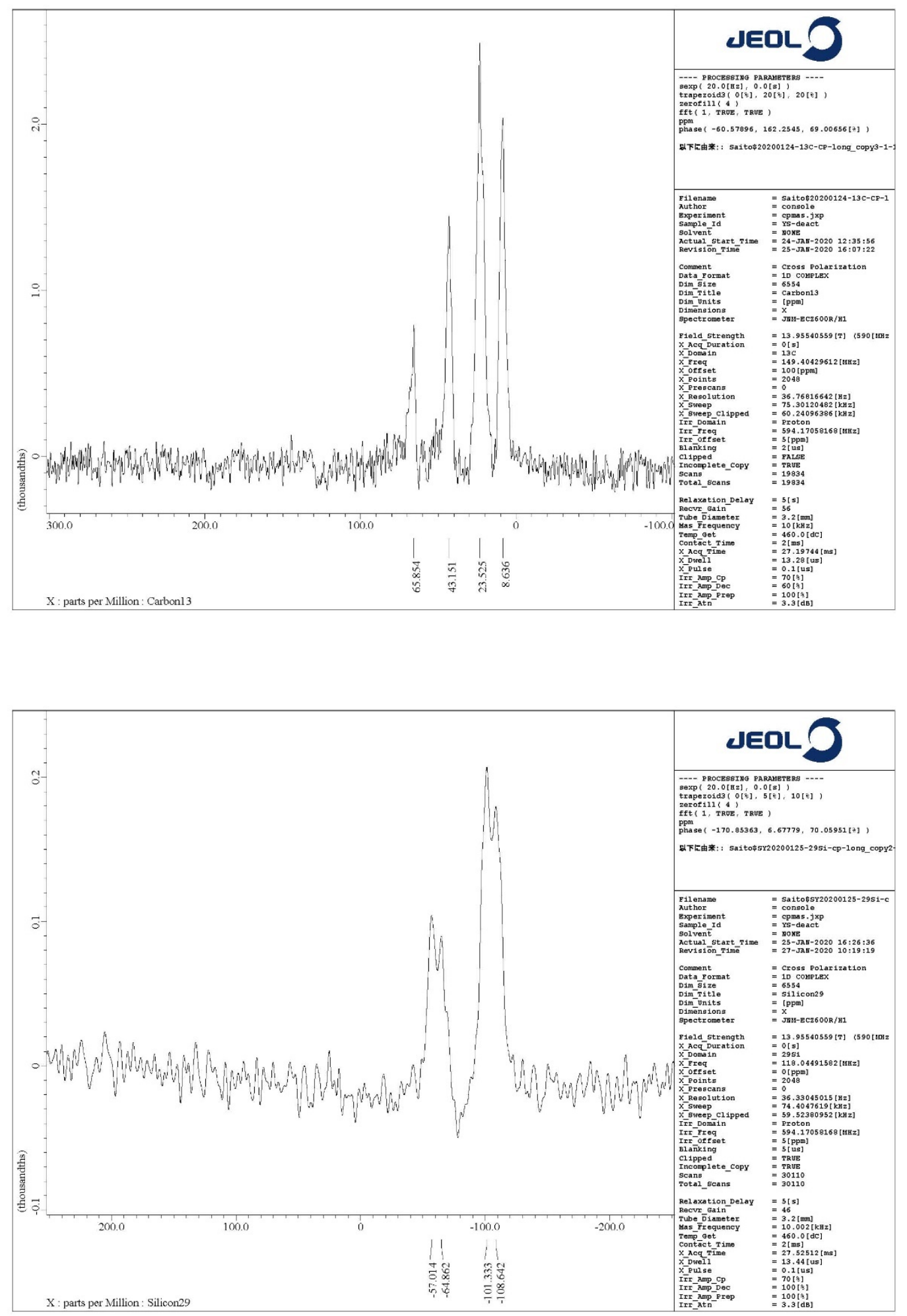


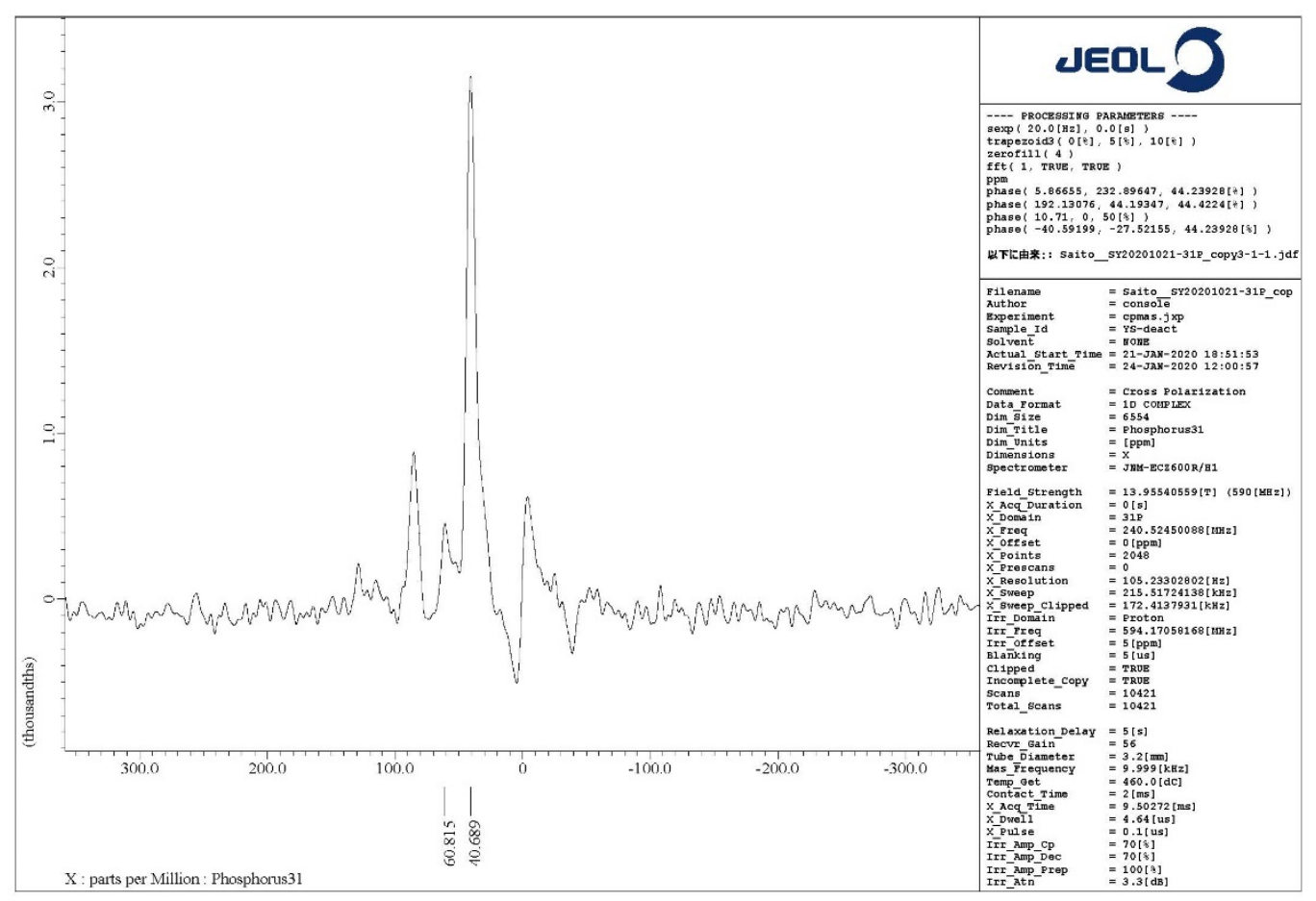

Figure S4. Solid NMR of Fresh Rh-QuinoxP*/STA/KIT-6-NH $\mathrm{N}_{2}$

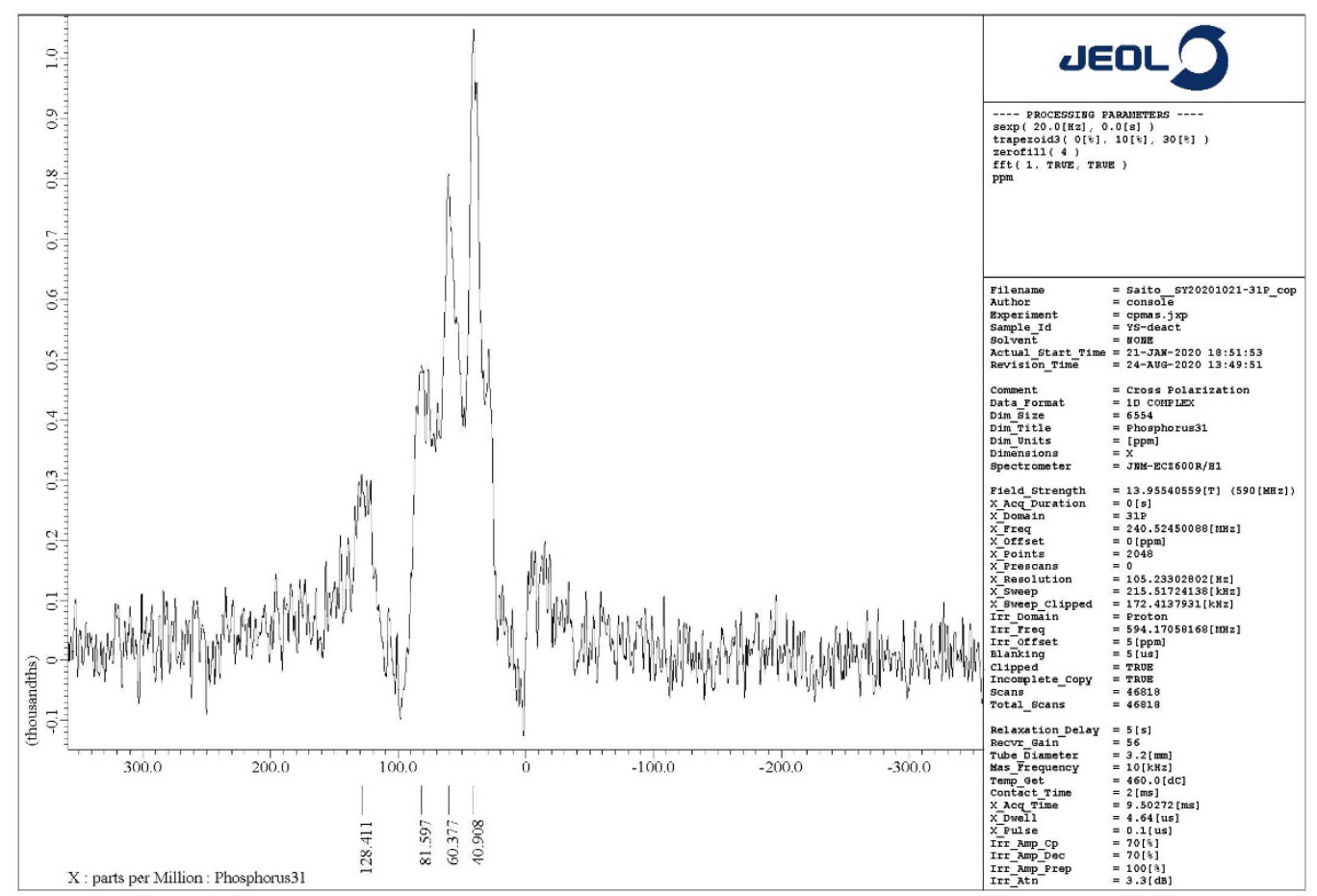

Figure S5. Solid NMR of Deactivated Rh-QuinoxP*/STA/KIT-6-NH $\mathrm{N}_{2}$ 
S-11 
s A general procedure of the continuous-flow hydrogenation of enamide $1 \mathbf{a}$.

5.(a) Set up of a fixed bed reactor

Inside a glovebox, to a $20 \mathrm{~mL}$ glass vial was added Rh-QuinoxP*/STA/KIT-6- $\mathrm{NH}_{2}(200 \mathrm{mg}$, Rh:0.01 mmol) and W-50 (600 mg) as solid dilutant. The solid was mixed well to get homogeneous solid, and packed into the SUS column $(\Phi 10 * 500 \mathrm{~mm})$ equipped with column end with a filter at the bottom. A Gas liquid mixer was equipped at the other end of column. The 3-way switcher was equipped with the inlet of both gas and liquid, and closed. The out let of the column was equipped with screw stopper to keep the whole system under Ar atmosphere.

\section{5.(b) Set up of substrate solution}

To a 2-neck $200 \mathrm{~mL}$ round bottom flask, enamide (1.63 g, $10 \mathrm{mmol})$ was introduced, and the atmosphere was changed to Ar. Toluene $(50 \mathrm{~mL})$ and ${ }^{i} \mathrm{PrOH}(50 \mathrm{~mL})$ was added to the flask, and stirred to prepare homogeneous solution. The solution was kept under Ar balloon.

\section{5.(c) Pretreatment of flow system}

A Hydrogen cylinder and a mass flow controller was equipped at the 3-way switcher for gas inlet. $\mathrm{H}_{2}$ gas was flowed at the rate of $25 \mathrm{~mL} / \mathrm{min}$ and introduced into the fixed bed reactor. The screw stopper at the end of catalyst column was removed after introducing $\mathrm{H}_{2}$ gas. The $\mathrm{H}_{2}$ gas flow was continued until the end of flow reaction. A plunger pump and pressure monitor was introduced at the 3 -way switcher for liquid inlet. Toluene was flowed at the flow rate of $0.2 \mathrm{~mL} / \mathrm{min}$ and introduced into the fixed bed reactor. The reactor was heated at 30 ${ }^{\circ} \mathrm{C}$. At this point, flow rate of solution was adjusted to get target one. Finally, back pressure regulator was equipped at the end of column, and the pressure of $\mathrm{H}_{2}$ gas was adjusted to 5 atm.

\section{5.(d) Catalytic hydrogenation of enamide}

The inlet of plunger pump was changed from toluene to substrate solution to start the flow hydrogenation. The resulting solution from the end of reactor was collected into a vial every $1 \mathrm{~h} .3 \mathrm{~mL}$ of the solution was taken from the vial, and evaporated to get crude material (51.6 $\mathrm{mg})$. After $1 \mathrm{H}$ NMR analysis, it was purified by preparative TLC to get target amide (49.0 $\mathrm{mg}$ ) as a white solid. Enantioselectivity was determined by HPLC analysis. Another $2 \mathrm{~mL}$ of resulting solution was evaporated, and treated with $\mathrm{H}_{2} \mathrm{SO}_{4} / \mathrm{HNO}_{3}$ to decompose organic material. The resulting solution was diluted with $\mathrm{H}_{2} \mathrm{O}$ up to $25 \mathrm{~mL}$. The solution was analyzed by ICP-AES to determine the Rh leaching. The flow reaction was continued for $24 \mathrm{~h}$. 
5. A general procedure of substrate scope in the continuous-flow hydrogenation of enamides The reaction was performed by following procedures described in above. Flow reactions were continued for $24 \mathrm{~h}$, and the resulting solution was analyzed at the stage of 3,15 , and $24 \mathrm{~h}$ after flow started. $1 \mathrm{~mL}$ of the resulting solution was used to determine yield and enantioselectivity. After removing solvent, the crude mixture was purified by preparative TLC (Hexane:Ethyl acetate $=1: 3)$ to obtain isolated product. Enantioselectivity was determined by HPLC analysis.

6. Optimization and a general procedure for o-substituted Enamides

The initial trial of asymmetric hydrogenation of o-substituted enamide $2 \mathbf{i}$ using standard catalyst resulted in significantly decreased enantioselectivity. Accordingly, catalyst with different chiral ligand was prepared following standard procedure, and used for flow asymmetric hydrogenation. The results were summarized in table S-2.

[Procedure for catalyst preparation]

STA/KIT-6- $\mathrm{NH}_{2}$ was prepared by following the standard procedure described above . To an oven dried test tube equipped with magnetic stirring bar was added STA/KIT-6- $\mathrm{NH}_{2}$ (100 $\mathrm{mg})$. The solid was dried under vacuo at room temperature for $1 \mathrm{~h}$. Meanwhile, to an another oven died test tube was added $\mathrm{Rh}(\mathrm{nbd}){ }_{2} \mathrm{BF}_{4}(1.9 \mathrm{mg}, 0.005 \mathrm{mmol})$ and chiral phosphite $\mathrm{L}$ (4.6 $\mathrm{mg}, 0.011 \mathrm{mmol}) .{ }^{i} \mathrm{PrOH}(1 \mathrm{~mL})$ was added to the flask, and the solution was stirred at room temperature for $1 \mathrm{~h}$ to give orange solution of $\mathrm{Rh}-\mathrm{L}$ complex. ${ }^{\mathrm{P}} \mathrm{PrOH}(1 \mathrm{~mL})$ was added to the flask with support material, and the solution of Rh complex via cannula. The mixture was stirred for $3 \mathrm{~h}$ at room temperature. The flask was centrifuged at 3,000 rpm for $15 \mathrm{~min}$. After completion of centrifugation, the supernatant was removed by cannula. To the flask ${ }^{i} \mathrm{PrOH}$ $(2 \mathrm{~mL})$ was added and stirred for $10 \mathrm{~min}$ at room temperature. This washing process was repeated for 5 times, and after removal of supernatant, the solid was dried under vacuo at room temperature for $3 \mathrm{~h}$. The $\mathrm{Rh}-\mathrm{L} / \mathrm{STA} / \mathrm{KIT}-6-\mathrm{NH}_{2}$ was obtained as orange solid (101 mg).

Table S3. Optimization for orth-substituted enamide 1i under continuous-flow conditions 


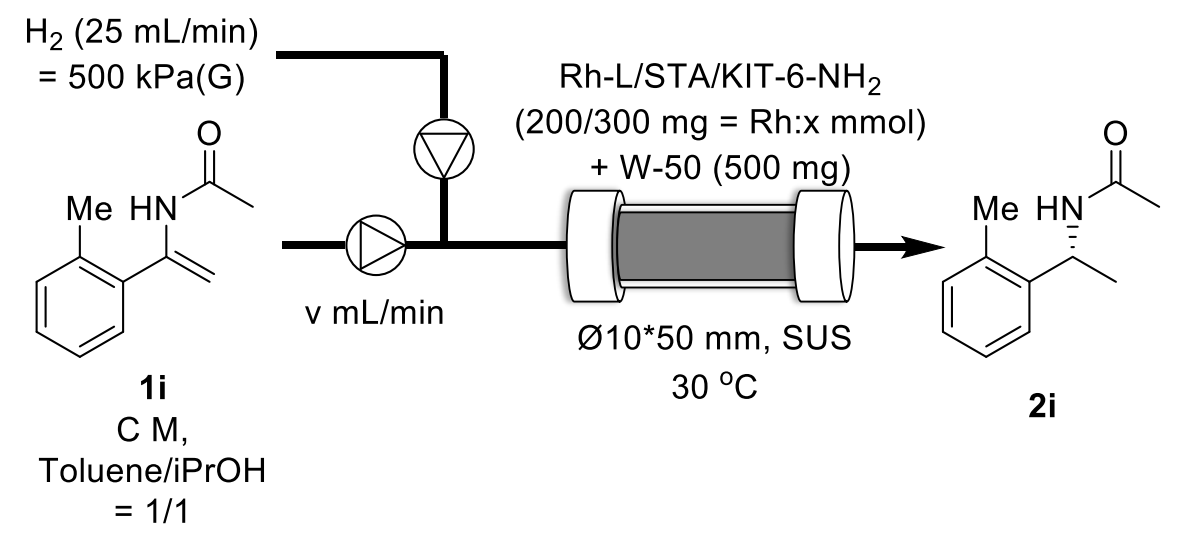<smiles>CP(c1nc2ccccc2nc1[Pb](C)(C)C)C(C)(C)C</smiles>

QuinoxP*<smiles>CCCCOP(OCCCC)Oc1c(C)cc2ccccc2c1-c1cc2ccccc2cc1C</smiles>

$\mathbf{L}$

\begin{tabular}{|l|l|l|l|l|l|l|}
\hline Entry & Ligand & Conc. (M) & $\mathrm{V}(\mathrm{mL} / \mathrm{min})$ & $\mathrm{X}(\mathrm{mmol})$ & Yield (\%) & Ee (\%) \\
\hline 1 & QuinoxP* & 0.2 & 0.1 & 0.01 & 71 & 30 \\
\hline 2 & L & 0.025 & 0.2 & 0.01 & 12 & N.D. \\
\hline 3 & L & 0.025 & 0.07 & 0.01 & 37 & 90 \\
\hline 4 & L & 0.025 & 0.07 & 0.015 & 51 & 90 \\
\hline 5 & L & 0.0125 & 0.07 & 0.015 & 95 & 90 \\
\hline
\end{tabular}

[A general procedure for orth-substituted enamide $1 \mathrm{i}$ under continuous-flow conditions]

Flow reactor was set up by following the same method as the standard enamide 1a using RhL/STA/KIT-6- $\mathrm{NH}_{2}$ instead of Rh-QuinoxP*/STA/KIT-6- $\mathrm{NH}_{2}$. Flow reactions were continued for $24 \mathrm{~h}$, and the resulting solution was analyzed at the stage of 3,15 , and $24 \mathrm{~h}$ after flow started. $1 \mathrm{~mL}$ of the resulting solution was used to determine yield and enantioselectivity. After removing solvent, the crude mixture was purified by preparative TLC (Hexane:Ethyl acetate $=1: 3)$ to obtain isolated product. Enantioselectivity was determined by HPLC analysis.

7. Optimization for 2-Naph Enamides

The initial trial of asymmetric hydrogenation of enamide 2o using standard catalyst resulted in decreased yield. Accordingly, catalysts with different chiral ligand was prepared following standard procedure, and used for flow asymmetric hydrogenation. The results were summarized in table S-3. 
[Procedure for catalyst preparation]

STA/KIT-6- $\mathrm{NH}_{2}$ was prepared by following the standard procedure described above. To an oven dried test tube equipped with magnetic stirring bar was added STA/KIT-6- $\mathrm{NH}_{2}$ (100 mg). The solid was dried under vacuo at room temperature for $1 \mathrm{~h}$. Meanwhile, to an another oven died test tube was added $\mathrm{Rh}(\mathrm{nbd}){ }_{2} \mathrm{BF}_{4}(1.9 \mathrm{mg}, 0.005 \mathrm{mmol})$ and chiral ligand $(4.6 \mathrm{mg}, 0.0055 \mathrm{mmol}){ }^{i} \mathrm{PrOH}(1 \mathrm{~mL})$ was added to the flask, and the solution was stirred at room temperature for $1 \mathrm{~h}$ to give orange solution of $\mathrm{Rh}-\mathrm{L}$ complex. ${ }^{i} \mathrm{PrOH}$ (1 $\mathrm{mL}$ ) was added to the flask with support material, and the solution of Rh complex via cannula. The mixture was stirred for $3 \mathrm{~h}$ at room temperature. The flask was centrifuged at 3,000 rpm for $15 \mathrm{~min}$. After completion of centrifugation, the supernatant was removed by cannula. To the flask ${ }^{2} \mathrm{PrOH}(2 \mathrm{~mL})$ was added and stirred for $10 \mathrm{~min}$ at room temperature. This washing process was repeated for 5 times, and after removal of supernatant, the solid was dried under vacuo at room temperature for $3 \mathrm{~h}$. The RhL/STA/KIT-6- $\mathrm{NH}_{2}$ was obtained as orange solid (101 mg).

Table S4. Optimization for orth-substituted enamide 1o under continuous-flow conditions

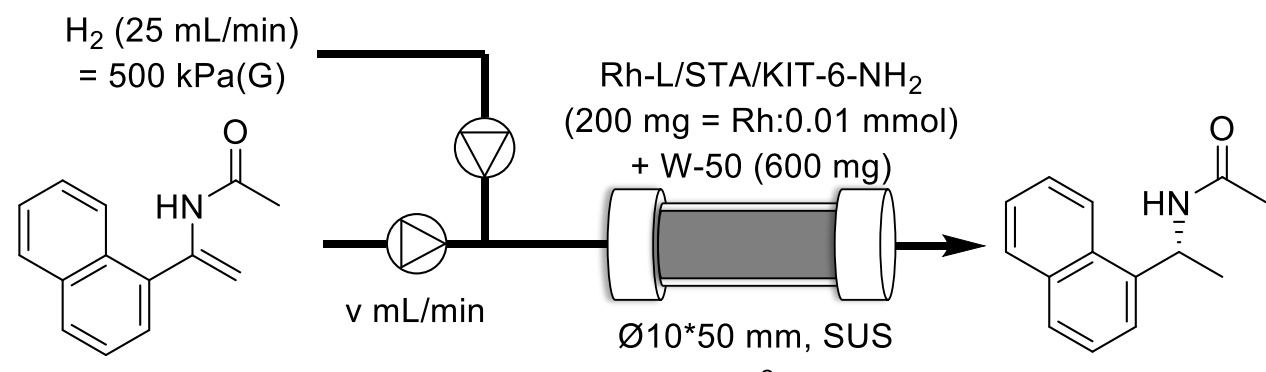

10, $\mathrm{C} \mathrm{M}$, Toluene/iPrOH = 1/1

$30^{\circ} \mathrm{C}$<smiles>CP([15CH3])c1nc2ccccc2nc1P(C)[Pb](C)C</smiles>

QuinoxP*<smiles></smiles>

PN<smiles>CP([18O][Mg])c1ccccc1[Pb](C)C</smiles>

BenzP*

\begin{tabular}{|c|c|c|c|c|}
\hline Entry & $\mathrm{L}$ & Conc. $(\mathrm{M})$ & $\mathrm{V}(\mathrm{mL} / \mathrm{min})$ & Yield(\%) \\
\hline 1 & QuinoxP* & 0.1 & 0.2 & 17 \\
\hline 2 & QuinoxP* & 0.1 & 0.1 & 35 \\
\hline 3 & PN & 0.1 & 0.1 & $<10$ \\
\hline 4 & BenzP* & 0.1 & 0.1 & 71 \\
\hline 5 & BenzP* & 0.05 & 0.1 & $91(93 \%$ ee) \\
\hline
\end{tabular}


[A procedure for orth-substituted enamide $1 \mathbf{i}$ under continuous-flow conditions]

Flow reactor was set up by following the same method as the standard enamide 1a using RhBenzP*/STA/KIT-6- $\mathrm{NH}_{2}$ instead of Rh-QuinoxP*/STA/KIT-6-NH2. Flow reactions were continued for $24 \mathrm{~h}$, and the resulting solution was analyzed at the stage of 3,15 , and $24 \mathrm{~h}$ after flow started. $1 \mathrm{~mL}$ of the resulting solution was used to determine yield and enantioselectivity. After removing solvent, the crude mixture was purified by preparative TLC (Hexane:Ethyl acetate $=1: 3)$ to obtain isolated product. Enantioselectivity was determined by HPLC analysis.

8. Comparison of batch and flow system<smiles>C=C(NC(C)=O)c1ccc(OC)cc1</smiles>

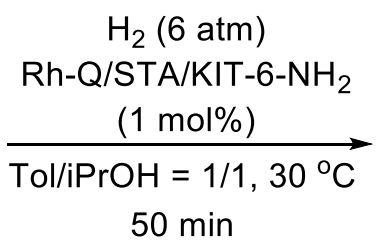<smiles>COc1ccc([C@H](C)NC(C)=O)cc1</smiles>

$76 \%$ yield

TOF: $91 \mathrm{~h}-1$

$99 \%$ ee

cf. Flow Yield: quant. TOF: $120 \mathrm{~h}-1$ $99 \%$ ee

[A procedure for batch hydrogenation with heterogeneous catalyst]

To an oven dried flask equipped with stirring bar was added Rh-QuinoxP*/STA-KIT-6-NH2 and Enamide under Ar atmonsphere. After addition of solvent, the flask was purged with $\mathrm{H}_{2}$ (3 atm), and the mixture was stirred for $50 \mathrm{~min}$ at $30^{\circ} \mathrm{C}$. After removing solvent, the crude mixture was purified by preparative TLC (Hexane:Ethyl acetate $=1: 3$ ) to obtain isolated product. Enantioselectivity was determined by HPLC analysis.

Comparison of the yield between batch and flow system indicates the superior activity under flow conditions. We reasoned the higher activity can be explained by the efficient $\mathrm{H}_{2}$ gas transfer to the heterogeneous catalyst.

Additionally, catalyst recovery and recycle were examined under batch conditions, the recovered catalyst showed significantly low yield (23\%) in the second run. Because the catalyst is not stable toward moisture and air, small contamination of air during recovery procedure may cause the deactivation. In contrast, flow reactions minimized the chance of such contamination and demonstrated high stability with $>10,000$ TON. 


\section{Product Data}

(R)-N-(1-phenylethyl)acetamide $(2 \mathbf{a})^{11}$

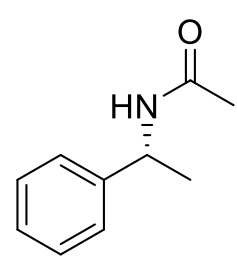

white solid, $49.0 \mathrm{mg}$

${ }^{1} \mathrm{H}$ NMR $\left(600 \mathrm{MHz}, \mathrm{CDCl}_{3}\right): \delta$ 7.32-28 (4H, m), 7.25-7.23 $(1 \mathrm{H}, \mathrm{m}), 6.30(1 \mathrm{H}$, $\mathrm{d}, J=5.50 \mathrm{~Hz}), 5.08(1 \mathrm{H}, \mathrm{dq}, J=6.87,7.56 \mathrm{~Hz}), 1.93(3 \mathrm{H}, \mathrm{s}), 1.45(3 \mathrm{H}, \mathrm{d}, J$ $=6.87 \mathrm{~Hz}) ;{ }^{13} \mathrm{C} \mathrm{NMR}\left(150 \mathrm{MHz}, \mathrm{CDCl}_{3}\right): \delta 169.2,143.2,128.5,127.2,126.1$, 48.7, 23.2, 21.7; enantiomeric excess was determined by HPLC analysis with a Chiralpak AD-3 column (hexane: $\mathrm{PrOH}=95: 5,1.0 \mathrm{~mL} / \mathrm{min}, 220 \mathrm{~nm}$ ); major enantiomer $\mathrm{tR}=11.7$ min, minor enantiomer $\mathrm{t} R=15.6 \mathrm{~min}$.

(R)-N-(1-(m-tolyl)ethyl)acetamide (2b) ${ }^{12}$

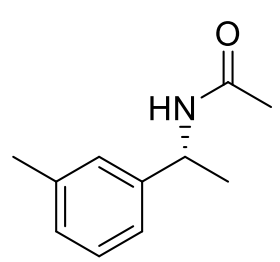

white solid, $53.1 \mathrm{mg} ;{ }^{1} \mathrm{H}$ NMR $\left(600 \mathrm{MHz}, \mathrm{CDCl}_{3}\right): \delta 7.23(1 \mathrm{H}, \mathrm{dd}, J=19.9$, $12.4 \mathrm{~Hz}), 7.13-7.05(3 \mathrm{H}, \mathrm{m}), 5.60(1 \mathrm{H}, \mathrm{s}), 5.07(1 \mathrm{H}, \mathrm{dq}, J=6.87,6.87$ $\mathrm{Hz}), 2.34(3 \mathrm{H}, \mathrm{s}), 1.96(3 \mathrm{H}, \mathrm{s}), 1.46(3 \mathrm{H}, \mathrm{d}, J=6.87 \mathrm{~Hz}) ;{ }^{13} \mathrm{C} \mathrm{NMR}(150$ $\left.\mathrm{MHz}_{\mathrm{CDCl}}\right)$ : $\delta 169.0,143.1,138.2,128.5,128.1,127.0,123.1,48.7,23.4$, 21.7, 21.4; enantiomeric excess was determined by HPLC analysis with a Chiralpak AD-3 column (hexane: ${ }^{2} \mathrm{PrOH}=95: 5,1.0 \mathrm{~mL} / \mathrm{min}, 220 \mathrm{~nm}$ ); major enantiomer tR $=9.7$ min, minor enantiomer $\mathrm{tR}=12.2 \mathrm{~min}$.

(R)-N-(1-(p-tolyl)ethyl)acetamide $(2 \mathrm{c})^{13}$<smiles>CC(=O)NC(C)c1ccc(C)cc1</smiles>
white solid, $52.9 \mathrm{mg} ;{ }^{1} \mathrm{H}$ NMR $\left(600 \mathrm{MHz}, \mathrm{CDCl}_{3}\right): \delta 7.21(2 \mathrm{H}, \mathrm{d}, J=8.25$ $\mathrm{Hz}), 7.14(2 \mathrm{H}, \mathrm{d}, J=7.56 \mathrm{~Hz}), 5.79(1 \mathrm{H}, \mathrm{s}), 5.08(1 \mathrm{H}, \mathrm{dq}, J=13.06,7.56$ $\mathrm{Hz}), 2.33(3 \mathrm{H}, \mathrm{s}), 1.96(3 \mathrm{H}, \mathrm{s}), 1.47(3 \mathrm{H}, \mathrm{d}, J=6.87 \mathrm{~Hz}) ;{ }^{13} \mathrm{C} \mathrm{NMR}(150$ $\left.\mathrm{MHz}_{\mathrm{CDCl}}\right): \delta 169.0,140.1,137.0,129.3,126.10,126.09,48.5,23.4$, 21.6, 21.0; enantiomeric excess was determined by HPLC analysis with a Chiralpak AD-3 column (hexane: ${ }^{i} \mathrm{PrOH}=95: 5,1.0 \mathrm{~mL} / \mathrm{min}, 210 \mathrm{~nm}$ ); major enantiomer tR $=12.2 \mathrm{~min}$, minor enantiomer $\mathrm{tR}=17.0 \mathrm{~min}$.

(R)-N-(1-(4-methoxyphenyl)ethyl)acetamide (2d $)^{12}$<smiles>COc1ccc(C(C)NC(C)=O)cc1</smiles>
white solid, $58.0 \mathrm{mg} ;{ }^{1} \mathrm{H} \mathrm{NMR}\left(600 \mathrm{MHz}, \mathrm{CDCl}_{3}\right): \delta 7.24(1 \mathrm{H}, \mathrm{d}, J=$ $8.25 \mathrm{~Hz}), 6.87(2 \mathrm{H}, \mathrm{d}, J=8.25 \mathrm{~Hz}), 5.76(1 \mathrm{H}, \mathrm{s}), 5.10-5.05(1 \mathrm{H}, \mathrm{m})$, $3.79(3 \mathrm{H}, \mathrm{s}), 1.96(3 \mathrm{H}, \mathrm{s}), 1.47(3 \mathrm{H}, \mathrm{d}, J=6.87 \mathrm{~Hz}) ;{ }^{13} \mathrm{C}$ NMR $(150$ $\left.\mathrm{MHz}_{\mathrm{CDCl}}\right): \delta 169.0,158.8,135.3,127.4,114.9,55.3,48.2,23.4$, 21.5; enantiomeric excess was determined by HPLC analysis with a Chiralpak AD-3 column (hexane: ${ }^{i} \mathrm{PrOH}=95: 5,1.0 \mathrm{~mL} / \mathrm{min}, 220 \mathrm{~nm}$ ); major enantiomer tR $=17.8 \mathrm{~min}$, minor enantiomer $\mathrm{tR}=24.2 \mathrm{~min}$. 
(R)-N-(1-(4-fluorophenyl)ethyl)acetamide (2e $)^{13}$<smiles>CC(=O)NC(C)c1ccc(F)cc1</smiles>

white solid, $54.3 \mathrm{mg} ;{ }^{1} \mathrm{H}$ NMR $\left(600 \mathrm{MHz}, \mathrm{CDCl}_{3}\right): \delta 7.28(1 \mathrm{H}, \mathrm{dd}, J=8.25$, $5.50 \mathrm{~Hz}), 7.01(2 \mathrm{H}, \mathrm{t}, J=8.94 \mathrm{~Hz}), 5.89(1 \mathrm{H}, \mathrm{s}), 5.12-5.07(1 \mathrm{H}, \mathrm{m}), 1.97$ $(3 \mathrm{H}, \mathrm{s}), 1.46(3 \mathrm{H}, \mathrm{d}, J=6.87 \mathrm{~Hz}) ;{ }^{13} \mathrm{C} \mathrm{NMR}\left(150 \mathrm{MHz}, \mathrm{CDCl}_{3}\right): \delta 169.1$, $161.9\left(\mathrm{~d}, J_{C-F}=243 \mathrm{~Hz}\right), 139.0,127.6\left(\mathrm{~d}, J_{C-F}=8.6 \mathrm{~Hz}\right), 115.4\left(\mathrm{~d}, J_{C-F}=\right.$ $20.1 \mathrm{~Hz}), 48.1,23.3,21.7$; 19F NMR (565 $\left.\mathrm{MHz}, \mathrm{CDCl}_{3}\right): \delta$-115.3; enantiomeric excess was determined by HPLC analysis with a Chiralpak AD-3 column (hexane: ${ }^{\mathrm{PrOH}}=95: 5,1.0 \mathrm{~mL} / \mathrm{min}, 210 \mathrm{~nm}$ ); major enantiomer $\mathrm{tR}=13.7 \mathrm{~min}$, minor enantiomer $\mathrm{tR}=17.8 \mathrm{~min}$.

(R)-N-(1-(4-chlorophenyl)ethyl)acetamide (2f) ${ }^{13}$

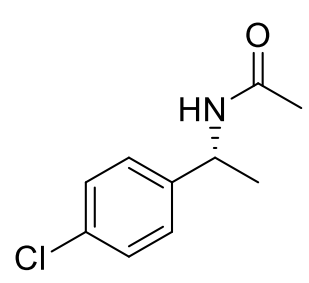

white solid, $60.0 \mathrm{mg} ;{ }^{1} \mathrm{H}$ NMR $\left(600 \mathrm{MHz}, \mathrm{CDCl}_{3}\right): \delta 7.29(1 \mathrm{H}, \mathrm{d}, J=8.25$ $\mathrm{Hz}), 7.24(2 \mathrm{H}, \mathrm{d}, J=8.25 \mathrm{~Hz}), 5.95(1 \mathrm{H}, \mathrm{s}), 5.09-5.05(1 \mathrm{H}, \mathrm{m}), 1.97$ $(3 \mathrm{H}, \mathrm{s}), 1.45(3 \mathrm{H}, \mathrm{d}, J=6.87 \mathrm{~Hz}) ;{ }^{13} \mathrm{C} \mathrm{NMR}\left(150 \mathrm{MHz}, \mathrm{CDCl}_{3}\right): \delta 169.2$, 141.8, 133.0, 128.7, 127.5, 48.2, 23.3, 21.7; enantiomeric excess was determined by HPLC analysis with a Chiralpak AD-3 column (hexane: ${ }^{i} \mathrm{PrOH}=95: 5,1.0 \mathrm{~mL} / \mathrm{min}, 220 \mathrm{~nm}$ ); major enantiomer $\mathrm{tR}=13.6 \mathrm{~min}$, minor enantiomer $\mathrm{tR}$ $=18.5 \mathrm{~min}$.

(R)-N-(1-(4-bromophenyl)ethyl)acetamide $(2 \mathrm{~g})^{12}$<smiles>CC(=O)NC(C)c1ccc(Br)cc1</smiles>
white solid, $68.8 \mathrm{mg} ;{ }^{1} \mathrm{H}$ NMR $\left(600 \mathrm{MHz}, \mathrm{CDCl}_{3}\right): \delta 7.25(2 \mathrm{H}, \mathrm{d}, J=8.25$ $\mathrm{Hz}), 7.19(2 \mathrm{H}, \mathrm{d}, J=8.25 \mathrm{~Hz}), 5.79(1 \mathrm{H}, \mathrm{s}), 5.09-5.04(1 \mathrm{H}, \mathrm{m}), 1.98$ $(3 \mathrm{H}, \mathrm{s}), 1.46(3 \mathrm{H}, \mathrm{d}, J=7.56 \mathrm{~Hz}) ;{ }^{13} \mathrm{C} \mathrm{NMR}\left(150 \mathrm{MHz}, \mathrm{CDCl}_{3}\right): \delta 169.1$, $142.3,131.7,127.9,121.1,48.2,23.4,21.7$; enantiomeric excess was determined by HPLC analysis with a Chiralpak AD-3 column (hexane: ${ }^{2} \mathrm{PrOH}=95: 5,1.0 \mathrm{~mL} / \mathrm{min}, 220 \mathrm{~nm}$ ); major enantiomer $\mathrm{tR}=16.1 \mathrm{~min}$, minor enantiomer $\mathrm{tR}$ $=21.8 \mathrm{~min}$.

(R)-N-(1-(4-nitrophenyl)ethyl)acetamide $(2 \mathbf{h})^{11}$

$\begin{aligned} & \text { pale yellow solid, } 62.5 \mathrm{mg} ;{ }^{1} \mathrm{H} \mathrm{NMR}\left(600 \mathrm{MHz}, \mathrm{CDCl}_{3}\right): \delta 8.17(2 \mathrm{H}, \mathrm{d} \text {, } \\ & J=8.25 \mathrm{~Hz}), 7.47(2 \mathrm{H}, \mathrm{d}, J=8.94 \mathrm{~Hz}), 6.18(1 \mathrm{H}, \mathrm{d}, J=6.19 \mathrm{~Hz}), 5.18-\end{aligned}$
$\begin{aligned} & \left.\mathrm{MHz}, \mathrm{CDCl}_{3}\right): \delta 169.5,151.0,147.0,126.9,123.8,48.5,23.2,21.8 ; \\ & \text { enantiomeric excess was determined by HPLC analysis with a }\end{aligned}$ Chiralpak AD-3 column (hexane: ${ }^{i} \mathrm{PrOH}=95: 5,1.0 \mathrm{~mL} / \mathrm{min}, 270 \mathrm{~nm}$ ); major enantiomer tR 
$=12.7$ min, minor enantiomer $\mathrm{tR}=23.7 \mathrm{~min}$.

(S)-N-(1-(o-tolyl)ethyl)acetamide (2i) ${ }^{14}$

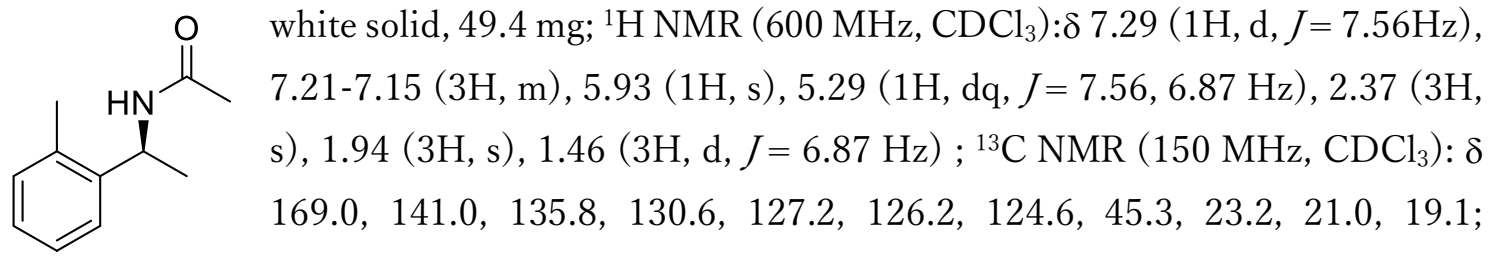
enantiomeric excess was determined by HPLC analysis with a Chiralpak AD-

3 column (hexane: ${ }^{\mathrm{PrOH}}=95: 5,1.0 \mathrm{~mL} / \mathrm{min}, 210 \mathrm{~nm}$ ); minor enantiomer $\mathrm{tR}=9.9 \mathrm{~min}$, major enantiomer $\mathrm{tR}=13.4 \mathrm{~min}$.

(S)-N-(1-(2-methoxyphenyl)ethyl)acetamide $(2 \mathbf{j})^{14}$<smiles>COc1ccccc1C(C)NC(C)=O</smiles>

white solid, $52.3 \mathrm{mg} ;{ }^{1} \mathrm{H}$ NMR $\left(600 \mathrm{MHz}, \mathrm{CDCl}_{3}\right): \delta$ 7.27-7.20 (2H, m), 6.93-6.89 (2H, m), $6.47(1 \mathrm{H}, \mathrm{d}, J=6.19 \mathrm{~Hz}), 5.26(1 \mathrm{H}, \mathrm{dt}, J=15.81,6.87$ $\mathrm{Hz}), 3.88(3 \mathrm{H}, \mathrm{s}), 1.96(3 \mathrm{H}, \mathrm{s}), 1.44(3 \mathrm{H}, \mathrm{d}, J=6.87 \mathrm{~Hz}) ;{ }^{13} \mathrm{C} \mathrm{NMR}(150$ $\left.\mathrm{MHz}_{2} \mathrm{CDCl}_{3}\right): \delta 168.8,157.0,130.8,128.4,128.0,120.8,111.0,55.3,47.3$, 23.5, 21.4; enantiomeric excess was determined by HPLC analysis with a Chiralpak AD-3 column (hexane: ${ }^{i} \mathrm{PrOH}=95: 5,1.0 \mathrm{~mL} / \mathrm{min}, 210 \mathrm{~nm}$ ); minor enantiomer tR $=16.3 \mathrm{~min}$, major enantiomer $\mathrm{tR}=24.1 \mathrm{~min}$.

(S)-N-(1-(2-chlorophenyl) ethyl)acetamide (2k) $)^{14}$<smiles>CC(=O)NC(C)c1ccccc1Cl</smiles>
white solid, $56.3 \mathrm{mg} ;{ }^{1} \mathrm{H}$ NMR $\left(600 \mathrm{MHz}, \mathrm{CDCl}_{3}\right): \delta 7.35(1 \mathrm{H}, \mathrm{dd}, J=7.56$, $1.37 \mathrm{~Hz}), 7.32(1 \mathrm{H}, \mathrm{dd}, J=7.56,1.37 \mathrm{~Hz}), 7.24(1 \mathrm{H}, \mathrm{t}, J=7.56 \mathrm{~Hz}), 7.19$ $(1 \mathrm{H}, \mathrm{td}, J=7.56,1.37 \mathrm{~Hz}), 6.04(1 \mathrm{H}, \mathrm{s}), 5.41-5.36(1 \mathrm{H}, \mathrm{m}), 1.99(3 \mathrm{H}, \mathrm{s})$, $1.48(3 \mathrm{H}, \mathrm{d}, J=6.87 \mathrm{~Hz}) ;{ }^{13} \mathrm{C} \mathrm{NMR}\left(150 \mathrm{MHz}, \mathrm{CDCl}_{3}\right): \delta 169.0,140.4$, $132.8,130.1,128.4,127.2,127.1,47.2,23.3,20.8$; enantiomeric excess was determined by HPLC analysis with a Chiralpak AD-3 column (hexane: ${ }^{2} \mathrm{PrOH}=95: 5,1.0$ $\mathrm{mL} / \mathrm{min}, 210 \mathrm{~nm}$ ); minor enantiomer $\mathrm{tR}=11.6 \mathrm{~min}$, major enantiomer $\mathrm{tR}=15.0 \mathrm{~min}$.

(S)-N-(1-(2-nitrophenyl)ethyl)acetamide (21) ${ }^{15}$<smiles>CC(=O)NC(C)c1ccccc1[N+](=O)[O-]</smiles>
pale yellow solid, $62.6 \mathrm{mg} ;{ }^{1} \mathrm{H}$ NMR $\left(600 \mathrm{MHz}, \mathrm{CDCl}_{3}\right): \delta 7.86(1 \mathrm{H}, \mathrm{d}, J=$ $8.94 \mathrm{~Hz}), 7.59-7.56(1 \mathrm{H}, \mathrm{m}), 7.51(1 \mathrm{H}, \mathrm{d}, J=6.87 \mathrm{~Hz}), 7.40-7.37(1 \mathrm{H}, \mathrm{m})$, $6.31(1 \mathrm{H}, \mathrm{d}, J=4.12 \mathrm{~Hz}), 5.51-5.46(1 \mathrm{H}, \mathrm{m}), 1.95(3 \mathrm{H}, \mathrm{s}), 1.53(3 \mathrm{H}, \mathrm{d}, J=$ $6.87 \mathrm{~Hz}) ;{ }^{13} \mathrm{C} \mathrm{NMR}\left(150 \mathrm{MHz}, \mathrm{CDCl}_{3}\right): \delta 169.3,148.6,138.7,133.3,128.6$, 128.0, 124.8, 46.6, 23.1, 21.3; enantiomeric excess was determined by HPLC analysis with a Chiralpak AD-3 column (hexane: ${ }^{i} \mathrm{PrOH}=95: 5,1.0 \mathrm{~mL} / \mathrm{min}, 250 \mathrm{~nm}$ ); minor 
enantiomer $\mathrm{tR}=22.0$ min, major enantiomer $\mathrm{t} R=26.9 \mathrm{~min}$.

(R)-N-(1-(3,4-dichlorophenyl)ethyl)acetamide $(2 \mathrm{~m})^{11}$<smiles>CC(=O)N[C@@H](C)c1ccc(Cl)c(Cl)c1</smiles>
white solid, $67.0 \mathrm{mg} ;{ }^{1} \mathrm{H}$ NMR $\left(600 \mathrm{MHz}, \mathrm{CDCl}_{3}\right): \delta$ 7.40-7.38 $(2 \mathrm{H}, \mathrm{m})$, $7.15(1 \mathrm{H}, \mathrm{dd}, J=8.25,2.06 \mathrm{~Hz}), 5.81(1 \mathrm{H}, \mathrm{s}), 5.08-5.03(1 \mathrm{H}, \mathrm{m}), 2.00$ $(3 \mathrm{H}, \mathrm{s}), 1.45(3 \mathrm{H}, \mathrm{d}, J=6.87 \mathrm{~Hz}) ;{ }^{13} \mathrm{C} \mathrm{NMR}\left(150 \mathrm{MHz}, \mathrm{CDCl}_{3}\right): \delta 169.3$, 143.7, 132.6, 131.1, 130.5, 128.1, 125.7, 47.9, 23.3, 21.7; enantiomeric excess was determined by HPLC analysis with a Chiralpak AD-3 column (hexane: ${ }^{\mathrm{PrOH}}=95: 5,1.0 \mathrm{~mL} / \mathrm{min}, 220 \mathrm{~nm}$ ); major enantiomer $\mathrm{tR}=10.4 \mathrm{~min}$, minor enantiomer $\mathrm{tR}=15.6$ min.

(R)-N-(1-(3-methoxyphenyl)ethyl) acetamide $(2 \mathbf{n})^{11}$<smiles>COc1cccc(C(C)NC(C)=O)c1</smiles>
white solid, $57.8 \mathrm{mg} ;{ }^{1} \mathrm{H}$ NMR $\left(600 \mathrm{MHz}, \mathrm{CDCl}_{3}\right): \delta$ 7.27-7.24 (1H, m), $6.90(1 \mathrm{H}, \mathrm{d}, J=7.56 \mathrm{~Hz}), 6.86(1 \mathrm{H}, \mathrm{t}, J=2.06 \mathrm{~Hz}), 6.80(1 \mathrm{H}, \mathrm{dd}, J=$ 8.25, 2.75 Hz), $5.80(1 \mathrm{H}, \mathrm{s}), 5.11-5.07(1 \mathrm{H}, \mathrm{m}), 3.80(3 \mathrm{H}, \mathrm{s}), 1.98(3 \mathrm{H}$, s), $1.47(3 \mathrm{H}, \mathrm{d}, J=6.87 \mathrm{~Hz}) ;{ }^{13} \mathrm{C} \mathrm{NMR}\left(150 \mathrm{MHz}, \mathrm{CDCl}_{3}\right): \delta 169.1$, $159.8,144.8,129.7,118.4,112.4,112.3,55.2,48.8,23.4,21.7$; enantiomeric excess was determined by HPLC analysis with a Chiralpak AD-3 column (hexane: ${ }^{\mathrm{PrOH}}=95: 5,1.0 \mathrm{~mL} / \mathrm{min}, 220 \mathrm{~nm}$ ); major enantiomer $\mathrm{tR}=21.9 \mathrm{~min}$, minor enantiomer $\mathrm{tR}=27.6 \mathrm{~min}$.

(R)-N-(1-(naphthalen-1-yl)ethyl)acetamide (2o $)^{11}$<smiles>CC(=O)NC(C)c1cccc2ccccc12</smiles>
white solid, $57.7 \mathrm{mg} ;{ }^{1} \mathrm{H}$ NMR $\left(600 \mathrm{MHz}, \mathrm{CDCl}_{3}\right): \delta 8.08(1 \mathrm{H}, \mathrm{d}, J=8.94$ $\mathrm{Hz}), 7.85(1 \mathrm{H}, \mathrm{d}, J=8.25 \mathrm{~Hz}), 7.78(1 \mathrm{H}, \mathrm{d}, J=8.25 \mathrm{~Hz}), 7.55-7.47(3 \mathrm{H}$, m), $7.43(1 \mathrm{H}, \mathrm{t}, J=7.56 \mathrm{~Hz}), 5.92-5.85(2 \mathrm{H}, \mathrm{m}), 1.93(3 \mathrm{H}, \mathrm{s}), 1.64(3 \mathrm{H}$, $\mathrm{d}, J=6.19 \mathrm{~Hz}) ;{ }^{13} \mathrm{C} \mathrm{NMR}\left(150 \mathrm{MHz}, \mathrm{CDCl}_{3}\right): \delta 168.9,138.2,133.9,131.1$, $128.7,128.3,126.5,125.8,125.1,123.4,122.5,44.6,23.3,20.6$; enantiomeric excess was determined by HPLC analysis with a Chiralpak AD-3 column (hexane: ${ }^{i} \mathrm{PrOH}=95: 5,1.0 \mathrm{~mL} / \mathrm{min}, 220 \mathrm{~nm}$ ); minor enantiomer $\mathrm{tR}=14.8 \mathrm{~min}$, major enantiomer $\mathrm{tR}=15.9 \mathrm{~min}$.

methyl acetyl-D-phenylalaninate $(\mathbf{4 a})^{11}$<smiles>CC(=O)N[C@@H](Cc1ccccc1)C(C)=O</smiles>
white solid, $66.5 \mathrm{mg} ;{ }^{1} \mathrm{H}$ NMR $\left(600 \mathrm{MHz}, \mathrm{CDCl}_{3}\right): \delta 7.31-7.24(3 \mathrm{H}, \mathrm{m})$, $7.09(2 \mathrm{H}, \mathrm{d}, \mathrm{J}=6.87 \mathrm{~Hz}), 5.95(1 \mathrm{H}, \mathrm{d}, \mathrm{J}=6.87 \mathrm{~Hz}), 4.89(1 \mathrm{H}, \mathrm{td}, \mathrm{J}=$ 6.87, $5.04 \mathrm{~Hz}), 3.73(3 \mathrm{H}, \mathrm{s}), 3.15(1 \mathrm{H}, \mathrm{dd}, \mathrm{H}=13.75,5.50 \mathrm{~Hz}), 3.09$ $(1 \mathrm{H}, \mathrm{dd}, \mathrm{J}=14.09,5.84 \mathrm{~Hz}), 1.98(3 \mathrm{H}, \mathrm{s}) ;{ }^{13} \mathrm{C} \mathrm{NMR}(150 \mathrm{MHz}$, 
$\left.\mathrm{CDCl}_{3}\right): \delta 172.1,170.0,135.8,129.2,128.5,127.1,53.1,52.2,37.8,23.0$; enantiomeric excess was determined by HPLC analysis with a Chiralpak AD-3 column (hexane: ${ }^{i} \mathrm{PrOH}=90: 10$, $1.0 \mathrm{~mL} / \mathrm{min}, 220 \mathrm{~nm}$ ); major enantiomer $\mathrm{tR}=9.5 \mathrm{~min}$, minor enantiomer $\mathrm{tR}=13.5 \mathrm{~min}$.

methyl (R)-2-acetamido-3-(4-methoxyphenyl)propanoate (4b) $)^{14}$

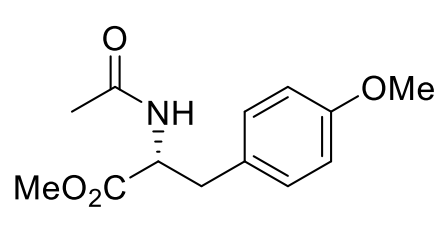
white solid, $75.5 \mathrm{mg} ;{ }^{1} \mathrm{H}$ NMR $\left(600 \mathrm{MHz}, \mathrm{CDCl}_{3}\right): \delta 7.01(2 \mathrm{H}, \mathrm{d}$, $J=8.94 \mathrm{~Hz}), 6.82(2 \mathrm{H}, \mathrm{d}, \mathrm{J}=8.94 \mathrm{~Hz}), 6.00(1 \mathrm{H}, \mathrm{d}, \mathrm{J}=7.56$ $\mathrm{Hz}), 4.84(1 \mathrm{H}, \mathrm{td}, \mathrm{J}=6.87,5.04 \mathrm{~Hz}), 3.78(3 \mathrm{H}, \mathrm{s}), 3.73(3 \mathrm{H}, \mathrm{s})$, $3.08(1 \mathrm{H}, \mathrm{d}, \mathrm{J}=13.75,5.50 \mathrm{~Hz}), 3.03(1 \mathrm{H}, \mathrm{dd}, \mathrm{J}=13.75,5.50$ $\mathrm{Hz}), \quad 1.98 \quad(3 \mathrm{H}, \quad \mathrm{s}) \quad ; \quad{ }^{13} \mathrm{C} \quad \mathrm{NMR} \quad\left(150 \quad \mathrm{MHz}, \quad \mathrm{CDCl}_{3}\right)$ : $\delta 172.2,169.6,158.6,130.2,127.7,113.9,55.1,53.2,52.2,36.9,23.1$; enantiomeric excess was determined by HPLC analysis with a Chiralpak AD-3 column (hexane: ${ }^{i} \mathrm{PrOH}=90: 10,1.0$ $\mathrm{mL} / \mathrm{min}, 220 \mathrm{~nm}$ ); major enantiomer $\mathrm{tR}=15.4 \mathrm{~min}$, minor enantiomer $\mathrm{tR}=21.9 \mathrm{~min}$.

methyl (R)-2-acetamido-3-(4-fluorophenyl)propanoate (4c) ${ }^{14}$<smiles>CC(=O)N[C@@H](Cc1ccc(F)cc1)C(C)=O</smiles>

s) white solid, $71.5 \mathrm{mg} ;{ }^{1} \mathrm{H}$ NMR $\left(600 \mathrm{MHz}, \mathrm{CDCl}_{3}\right): \delta 7.06(2 \mathrm{H}$, dd, $J=8.25,5.50 \mathrm{~Hz}), 6.98(2 \mathrm{H}, \mathrm{dd}, J=8.94,8.94 \mathrm{~Hz}), 6.10(1 \mathrm{H}, \mathrm{d}, J$ $=6.87 \mathrm{~Hz}), 4.87-4.84(1 \mathrm{H}, \mathrm{m}), 3.72(3 \mathrm{H}, \mathrm{s}), 3.14(3 \mathrm{H}, \mathrm{s}), 3.13(1 \mathrm{H}$, $\mathrm{dd}, J=13.75,6.19 \mathrm{~Hz}), 3.05(1 \mathrm{H}, \mathrm{dd}, J=14.09,5.84 \mathrm{~Hz}), 1.99(3 \mathrm{H}$,

$\delta$ 172.0, 169.6, 162.8, 161.1, 131.6, 131.5, 130.7, 130.6, 115.4, 115.3, 53.1, 52.3, 37.0, 23.0; enantiomeric excess was determined by HPLC analysis with a Chiralpak AD-3 column (hexane: ${ }^{i} \mathrm{PrOH}=90: 10,1.0 \mathrm{~mL} / \mathrm{min}, 210 \mathrm{~nm}$ ); major enantiomer $\mathrm{tR}=11.0 \mathrm{~min}$, minor enantiomer $\mathrm{tR}=14.6 \mathrm{~min}$.

methyl (R)-2-acetamido-3-(4-chlorophenyl)propanoate (4d) ${ }^{14}$<smiles>CC(=O)N[C@@H](Cc1ccc(Cl)cc1)C(C)=O</smiles>
white solid, $76.9 \mathrm{mg} ;{ }^{1} \mathrm{H}$ NMR $\left(600 \mathrm{MHz}, \mathrm{CDCl}_{3}\right): \delta 7.26(2 \mathrm{H}, \mathrm{d}, J$ $=8.25 \mathrm{~Hz}), 7.03(2 \mathrm{H}, \mathrm{d}, J=8.25 \mathrm{~Hz}), 5.98(1 \mathrm{H}, \mathrm{d}, J=6.87 \mathrm{~Hz})$, $4.87(1 \mathrm{H}, \mathrm{q}, J=6.42 \mathrm{~Hz}), 3.73(3 \mathrm{H}, \mathrm{s}), 3.14(1 \mathrm{H}, \mathrm{dd}, J=13.75$, $6.19 \mathrm{~Hz}), 3.06(1 \mathrm{H}, \mathrm{dd}, J=13.75,5.50 \mathrm{~Hz}), 1.99(3 \mathrm{H}, \mathrm{s}) ;{ }^{13} \mathrm{C}$ $\operatorname{NMR}\left(150 \mathrm{MHz}, \mathrm{CDCl}_{3}\right)$ : $\delta 171.8,169.6,134.3,133.0,130.5,128.7,53.0,52.4,37.2,23.1$; enantiomeric excess was determined by HPLC analysis with a Chiralpak AD-3 column (hexane: ${ }^{i} \mathrm{PrOH}=90: 10,1.0 \mathrm{~mL} / \mathrm{min}, 220 \mathrm{~nm}$ ); major enantiomer $\mathrm{tR}=12.3 \mathrm{~min}$, minor enantiomer $\mathrm{t} R=15.8 \mathrm{~min}$.

methyl (R)-2-acetamido-3-(4-bromophenyl)propanoate $(4 \mathbf{e})^{16}$ 
<smiles>CC(=O)N[C@@H](Cc1ccc(Br)cc1)C(C)=O</smiles>

white solid, $90.6 \mathrm{mg} ;{ }^{1} \mathrm{H} \mathrm{NMR}\left(600 \mathrm{MHz}, \mathrm{CDCl}_{3}\right): \delta 7.41(2 \mathrm{H}, \mathrm{d}, J$ $=8.25 \mathrm{~Hz}), 6.97(2 \mathrm{H}, \mathrm{d}, J=8.25 \mathrm{~Hz}), 5.99(1 \mathrm{H}, \mathrm{d}, J=6.87 \mathrm{~Hz})$, $4.87(1 \mathrm{H}, \mathrm{q}, J=6.42 \mathrm{~Hz}), 3.73(3 \mathrm{H}, \mathrm{s}), 3.12(1 \mathrm{H}, \mathrm{dd}, J=13.74$, $6.19 \mathrm{~Hz}), 3.04(1 \mathrm{H}, \mathrm{dd}, J=5.50 \mathrm{~Hz}), 1.99(3 \mathrm{H}, \mathrm{s}) ;{ }^{13} \mathrm{C} \mathrm{NMR}(150$ $\mathrm{MHz}_{\mathrm{CDCl}}$ ): $\delta 171.8,169.6,134.9,131.6,130.9,121.1,52.9,52.4,37.3$, 23.1; enantiomeric excess was determined by HPLC analysis with a Chiralpak AD-3 column (hexane: ${ }^{i} \mathrm{PrOH}=$ 90:10, $1.0 \mathrm{~mL} / \mathrm{min}, 220 \mathrm{~nm}$ ); major enantiomer $\mathrm{tR}=12.9 \mathrm{~min}$, minor enantiomer $\mathrm{tR}=17.2$ $\min$.

methyl (R)-2-acetamido-3-(2-bromophenyl)propanoate (4f) ${ }^{17}$<smiles>CC(=O)N[C@@H](Cc1ccccc1Br)C(C)=O</smiles>
white solid, $90.5 \mathrm{mg} ;{ }^{1} \mathrm{H}$ NMR $\left(600 \mathrm{MHz}, \mathrm{CDCl}_{3}\right): \delta 7.55(1 \mathrm{H}, \mathrm{d}, J=$ $8.25 \mathrm{~Hz}), 7.25(1 \mathrm{H}, \mathrm{t}, J=7.56 \mathrm{~Hz}), 7.20(1 \mathrm{H}, \mathrm{d}, J=7.56 \mathrm{~Hz}), 7.12$ $(1 \mathrm{H}, \mathrm{t}, J=7.56 \mathrm{~Hz}), 6.04(1 \mathrm{H}, \mathrm{d}, J=7.56 \mathrm{~Hz}), 4.92(1 \mathrm{H}, \mathrm{q}, J=7.33$ $\mathrm{Hz}), 3.73(3 \mathrm{H}, \mathrm{s}), 3.32(1 \mathrm{H}, \mathrm{dd}, J=14.43,6.19 \mathrm{~Hz}), 3.19(1 \mathrm{H}, \mathrm{dd}, J=$ 13.75, $7.56 \mathrm{~Hz}), 1.96(3 \mathrm{H}, \mathrm{s}) ;{ }^{13} \mathrm{C} \mathrm{NMR}\left(150 \mathrm{MHz}, \mathrm{CDCl}_{3}\right): \delta 172.1,169.6,135.9,133.0$, $131.2,128.8,127.6,125.0,52.54,52.48,37.8,23.1$; enantiomeric excess was determined by HPLC analysis with a Chiralpak AD-3 column (hexane: ${ }^{\mathrm{PrOH}}=90: 10,1.0 \mathrm{~mL} / \mathrm{min}, 220$ $\mathrm{nm}$ ); major enantiomer $\mathrm{tR}=11.3 \mathrm{~min}$, minor enantiomer $\mathrm{tR}=16.1 \mathrm{~min}$.

methyl (R)-3-acetamidobutanoate $(6 \mathbf{a})^{11}$<smiles>COCCC(C)NC(C)=O</smiles>

colorless oil, $47.8 \mathrm{mg} ;{ }^{1} \mathrm{H}$ NMR $\left(600 \mathrm{MHz}, \mathrm{CDCl}_{3}\right): \delta 6.24(1 \mathrm{H}, \mathrm{s}), 4.37-$ $4.33(1 \mathrm{H}, \mathrm{m}), 3.70(3 \mathrm{H}, \mathrm{s}), 2.53(2 \mathrm{H}, \mathrm{d}, J=5.50 \mathrm{~Hz}), 1.97(3 \mathrm{H}, \mathrm{s}), 1.23$ $(3 \mathrm{H}, \mathrm{d}, J=6.87 \mathrm{~Hz}) ;{ }^{13} \mathrm{C} \mathrm{NMR}\left(150 \mathrm{MHz}, \mathrm{CDCl}_{3}\right): \delta 172.1,169.3,51.6$, 41.9, 39.7, 23.3, 19.9; enantiomeric excess was determined by HPLC analysis with a Chiralpak AD-3 column (hexane: ${ }^{2} \mathrm{PrOH}=90: 10,1.0 \mathrm{~mL} / \mathrm{min}, 220 \mathrm{~nm}$ ); major enantiomer $\mathrm{t} R=19.8 \mathrm{~min}$, minor enantiomer $\mathrm{t} R=21.4 \mathrm{~min}$.

methyl (R)-3-acetamidopentanoate $(6 \mathbf{b})^{11}$<smiles>CCC(CCOC)NC(C)=O</smiles>
colorless oil, $52.1 \mathrm{mg} ;{ }^{1} \mathrm{H}$ NMR $\left(600 \mathrm{MHz}, \mathrm{CDCl}_{3}\right): \delta 6.03(1 \mathrm{H}, \mathrm{s}), 4.11-$ $4.06(1 \mathrm{H}, \mathrm{m}), 3.62(3 \mathrm{H}, \mathrm{s}), 2.49(1 \mathrm{H}, \mathrm{dd}, J=15.81,5.50 \mathrm{~Hz}), 2.45(1 \mathrm{H}$, $\mathrm{dd}, J=15.81,5.50 \mathrm{~Hz}), 1.91(3 \mathrm{H}, \mathrm{s}), 1.49(2 \mathrm{H}, \mathrm{dq}, J=4.81,7.56 \mathrm{~Hz})$, $0.85(3 \mathrm{H}, \mathrm{t}, J=7.56 \mathrm{~Hz}) ;{ }^{13} \mathrm{C} \mathrm{NMR}\left(150 \mathrm{MHz}, \mathrm{CDCl}_{3}\right): \delta 172.4,169.5$, 51.6, 47.4, 37.8, 27.0, 23.4, 10.6; enantiomeric excess was determined by HPLC analysis with a Chiralpak AD-3 column (hexane: ${ }^{i} \mathrm{PrOH}=90: 10,1.0 \mathrm{~mL} / \mathrm{min}, 220 \mathrm{~nm}$ ); major enantiomer $\mathrm{tR}=13.9 \mathrm{~min}$, minor enantiomer $\mathrm{t} \mathrm{R}=15.8 \mathrm{~min}$. 
10. NMR and HPLC chart

Please see the attached PDF file. 


\section{References}

1. Deng, X. H.; Chen, K.; Tuysuz, H., Protocol for the Nanocasting Method: Preparation of Ordered Mesoporous Metal Oxides. Chem. Mater. 2017, 29, 40-52.

2. Imamoto, T.; Sugita, K.; Yoshida, K., An air-stable P-chiral phosphine ligand for highly enantioselective transition-metal-catalyzed reactions. J. Am. Chem. Soc. 2005, 127, 11934-11935. 3. Zhang, W. C.; Zhang, X. M., Synthesis of triphosphorous bidentate phosphinephosphoramidite ligands: Application in the highly enantioselective hydrogenation of orthosubstituted aryl enarnides. Angew. Chem., Int. Ed. 2006, 45, 5515-5518.

4. Lefort, L.; Boogers, J. A. F.; Kuilman, T.; Vijn, R. J.; Janssen, J.; Straatman, H.; de Vries, J. G.; de Vries, A. H. M., Rapid Identification of a Scalable Catalyst for the Asymmetric Hydrogenation of a Sterically Demanding Aryl Enamide. Org. Process Res. Dev. 2010, 14, 568573.

5. Hesp, K. D.; Bergman, R. G.; Ellman, J. A., Expedient Synthesis of N-Acyl Anthranilamides and beta-Enamine Amides by the Rh(III)-Catalyzed Amidation of Aryl and Vinyl C-H Bonds with Isocyanates. J. Am. Chem. Soc. 2011, 133, 11430-11433.

6. $\quad$ Reeves, J. T.; Tan, Z. L.; Han, Z. X. S.; Li, G. S.; Zhang, Y. D.; Xu, Y. B.; Reeves, D. C.; Gonnella, N. C.; Ma, S. L.; Lee, H.; Lu, B. Z.; Senanayake, C. H., Direct Titanium-Mediated Conversion of Ketones into Enamides with Ammonia and Acetic Anhydride. Angew. Chem., Int. Ed. 2012, 51, 1400-1404.

7. Jursic, B. S.; Sagiraju, S.; Ancalade, D. K.; Clark, T.; Stevens, E. D., Practical preparation of Z-alpha-(N-acetylamino)- and Z-alpha-(N-benzoylamino)-alpha,beta-unsaturated acids. Synth. Commun. 2007, 37, 1709-1714.

8. Zheng, Y. H.; Li, X. M.; Ren, C. F.; Zhang-Negrerie, D.; Du, Y. F.; Zhao, K., Synthesis of Oxazoles from Enamides via Phenyliodine Diacetate-Mediated Intramolecular Oxidative Cyclization. J. Org. Chem. 2012, 77, 10353-10361.

9. Li, G. L.; Antilla, J. C., Highly Enantioselective Hydrogenation of Enamides Catalyzed by Chiral Phosphoric Acids. Org. Lett. 2009, 11, 1075-1078.

10. Gorske, B. C.; Stringer, J. R.; Bastian, B. L.; Fowler, S. A.; Blackwell, H. E., New Strategies for the Design of Folded Peptoids Revealed by a Survey of Noncovalent Interactions in Model Systems. J. Am. Chem. Soc. 2009, 131, 16555-16567.

11. Imamoto, T.; Tamura, K.; Zhang, Z. F.; Horiuchi, Y.; Sugiya, M.; Yoshida, K.; Yanagisawa, A.; Gridnev, I. D., Rigid P-Chiral Phosphine Ligands with tertButylmethylphosphino Groups for Rhodium-Catalyzed Asymmetric Hydrogenation of Functionalized Alkenes. J. Am. Chem. Soc. 2012, 134, 1754-1769.

12. Li, X. S.; Jia, X.; Xu, L. J.; Kok, S. H. L.; Yip, C. W.; Chan, A. S. C., Highly air- and waterstable fluorinated ferrocenylphosphine-aminophosphine ligands and their applications in 
asymmetric hydrogenations. Adv. Synth. Catal. 2005, 347, 1904-1908.

13. Zhang, F. Y.; Pai, C. C.; Chan, A. S. C., Asymmetric synthesis of chiral amine derivatives through enantioselective hydrogenation with a highly effective rhodium catalyst containing a chiral bisaminophosphine ligand. J. Am. Chem. Soc. 1998, 120, 5808-5809.

14. Mohar, B.; Stephan, M., Practical Enantioselective Hydrogenation of -Aryl- and Carboxyamidoethylenes by Rhodium(I)-\{1,2-Bis (o-tert-butoxyphenyl)(phenyl)phosphino ethane\}. Adv. Synth. Catal. 2013, 355, 594-600.

15. Fowler, S. A.; Luechapanichkul, R.; Blackwell, H. E., Synthesis and Characterization of Nitroaromatic Peptoids: Fine Tuning Peptoid Secondary Structure through Monomer Position and Functionality. J. Org. Chem. 2009, 74, 1440-1449.

16. Jia, J.; Ling, Z.; Zhang, Z. F.; Tamura, K.; Gridnev, I. D.; Imamoto, T.; Zhang, W. B., An Atropos Chiral Biphenyl Bisphosphine Ligand Bearing Only 2,2 '-Substituents and Its Application in Rh-Catalyzed Asymmetric Hydrogenation. Adv. Synth. Catal. 2018, 360, 738-743.

17. Burk, M. J.; Lee, J. R.; Martinez, J. P., A Versatile Tandem Catalysis Procedure for the Preparation of Novel Amino-acids and Peptides. J. Am. Chem. Soc. 1994, 116, 10847-10848. 